\title{
Research on Deficiency of Intangible Cultural Heritage Education in Colleges and Its Countermeasures
}

\author{
Fang Chen \\ School of Fine Arts \\ Huanggang Normal College \\ Huanggang, China
}

\begin{abstract}
At present, the intangible cultural heritage receives scientific protection and needs the participation of more college students. But college students fail to receive the intangible cultural heritage education. So it is of great significance to explore the solution to this problem.
\end{abstract}

Keywords-colleges; intangible cultural heritage; intangible cultural heritage education; deficiency; countermeasure research

\section{INTRODUCTION}

Intangible cultural heritage is the cultural embodiment of production and life style of each nation and the wisdom crystallization of human culture. The educational value in it has great influence on college students' knowledge structure, moral character, value pursuit, national identity and aesthetic taste. It is the source for comprehensive education of college students.

\section{ANALYSIS ON THE RELATIONSHIP BETWEEN} EduCATIONAL VALUE OF InTANGIBLE CUltural Heritage AND COLLEGE STUDENTS’ GROWTH

\section{A. Humanistic Knowledge in Intangible Cultural Heritage Is the Beneficial Complement of College Students' \\ Knowledge Structure}

As an important carrier of humanistic knowledge, intangible cultural heritage "passes culture" in education. The intangible cultural heritage of our country has ten categories including more than one thousand national and eight thousand provincial and municipal lists. All of them involve rich and profound humanistic knowledge which can serve as beneficial complement of college students' humanistic education.

\section{B. Moral Character in Intangible Cultural Heritage Is the Source of College Students' Value Orientation}

Moral characters like "kindheartedness", "filial piety and fraternal duty", "benevolence", "self-sacrifice" and "patriotism" exist in the intangible cultural heritage of our country. It conforms to the socialist core value system. Besides, it is an important content in college students' comprehensive education. Strengthen the intangible cultural heritage education

Fund project: This paper is the research achievement of science and technology research project of Education Department of Hubei Province (Project No.: Q20152902). for college students, so we can greatly improve the awareness rate and attraction of intangible cultural heritage and resist the expansion of negative value pursuits like "materialism, money talks and enjoy life timely". It can develop continuously, healthily and vigorously in the establishment of college students' value system.

\section{Spiritual Outlook in Intangible Cultural Heritage Is the Source of College Students' National Spirit}

Intangible cultural heritage vividly shows national cultura spirit and aesthetic habits and continues life attitude and social behavior of a nation, and forms the tolerant and harmonious habits of people. Meanwhile, it reflects the identification and pride of a nation and the degree they are recognized by the world. It is an important link of cultural identity of a group or a nation. It is necessary to strengthen intangible cultural heritage education for college students through letting them learn the long history of Chinese nation and reminding them that the great rejuvenation of Chinese nation is the historical mission of them.

\section{Creative Spirit in Intangible Cultural Heritage Is the Power of College Students' Innovative Thinking}

Intangible cultural heritage is vivacious culture and collective intelligence created and inherited by people in the long term production and life practice. It keeps pace with the times. College students should carry out productive protection, innovation and reform of intangible cultural heritage and show its unique charm at the present times. College students are the constructer and successor of the beautiful Chinese dream and should be able to innovate. The productive protection of intangible cultural heritage provides platform for students' innovation and creates broad space for them.

\section{E. The Pursuit of Beauty in Intangible Cultural Heritage Is the Important Way to Improve College Students' Aesthetic Taste.}

Music and dance, fine arts skill and traditional Chinese opera in the intangible cultural heritage are culture and wisdom crystallization of people in pursuing beauty for thousands of years. The accumulated description and pursuit of beauty contain rich aesthetic knowledge. The intangible cultural 
heritage education for college students aims at improving aesthetic taste.

\section{ANALYSIS ON THE DEFICIENCY OF INTANGIBLE} Cultural Heritage EduCATION For COllege Students

At present, the protection of intangible cultural heritage has enjoyed popular support and attracted attention of the society. But the deficiency of intangible cultural heritage education for college students still exists.

\section{A. College Students Fail to Cognize and Participate in It.}

According to the survey, considerable college students fail to cognize the concept and the list of intangible cultural heritage and don't understand the policies and rules in protection of it. They know little about the intangible cultural heritage in their nations and area. Furthermore, influenced by economic development and globalization, some students are indifferent to the decay and disappearance of it. They have weak sense of responsibility in participating in the protection. College students receive education on campus and acquire information mainly through television, broadcast and network media. Because the intangible cultural heritage pays attention to "cultural ancient books" instead of "living culture", it makes traditional culture into rigid knowledge and doctrines which fail to arouse students' passion and interest in thinking and it separates from students' life.

\section{B. Intangible Cultural Heritage Education in Colleges Is Disordered and Fails to Enjoy Support}

On one hand, the absence and marginalization of some specialties seriously restricts the development and inheritance of intangible cultural heritage. Related disciplines like Folklore and Folk Literature are not introduced in the existing undergraduate education system. On the other hand, the absence of related disciplines leads to the incomplete system of intangible cultural heritage. Only a very few colleges provide disciplines like Folklore and Folk Literature in the undergraduate period. But they don't have clear teaching objectives and sound teaching plan. The teaching contents and methods are random and single. They fail to guarantee the basic class hour and credit. Moreover, the lack of teachers of intangible cultural heritage education in colleges greatly influences the quality and level of it. In recent years, some colleges establish the research center of intangible cultural heritage through integrating discipline resources and provide intangible cultural heritage education for college students. Restricted by discipline management, they outshine others or like a new force suddenly rise, failing to form effective force and lacking systematic teaching research.

\section{The Cultural and Ecological Environment in Society Is Blundering and It Lacks Positive Guidance}

The economy has increased rapidly since the reform and opening-up. However, nowadays, the cultural environment of Chinese people is influenced by the superficial western utilitarianism and extravagance. Pop stars guide most people's aesthetic taste and cultural quality. The popular urban mass culture separates from the traditional local culture, causing chaotic and stagnant cultural and ecological environment.

\section{WAys To Realize InTANGIBLE Cultural Heritage EDUCATION FOR COLLEGE STUDENTS}

\section{A. The Society Shall Optimize Cultural and Ecological Environment for the Intangible Cultural Heritage Education.}

In recent years, our country issues the Law of Intangible Cultural Heritage and establishes cultural ecological reserve and folk culture street as well as enriches the propaganda carrier to make the traditional national culture expose to the world. Although the protection of intangible cultural heritage is emphasized, it cannot keep up with the urbanization process. The reason is that the convenience brought by urbanization process and the lonely and slow localization form sharp contrast in the blundering social environment. People have got accustomed to the bustling city. It is difficult for them to understand the profound intangible cultural heritage. Therefore, in order to become a cultural fashion, the intangible cultural heritage must appeal to the urban people and reform, to become high-grade culture type and attract people's perceptual knowledge and appreciation. The society must create relax and diversified, active and tolerant cultural and ecological environment, follow the rule of market development as well as optimize the traditional national culture with rich value in creation, brand and operation. It can rise abruptly based on its accumulated strength and form cultural industry with virtuous cycle and enter people's life under the law of the market. The intangible cultural heritage can shine new charm through combination, expansion and improvement.

\section{B. The Country Shall Provide Policy Guarantee for the Integration of Intangible Cultural Heritage in College Education.}

The Article 34 of Chapter four in the Law of Intangible Cultural Heritage of People's Republic of China stipulates schools shall carry out intangible cultural heritage education according to the provisions of educational department of the State Council. It has made the task of colleges to implement intangible cultural heritage education become lawful. Undeniably, related policies are still ambiguous. At present, colleges haven't provided independent majors in undergraduate period, but the legal status of intangible cultural heritage education in colleges should be clear. It is a burgeoning academic sector. The protection of intangible cultural heritage in the 11th Five-year Plan has laid a solid foundation. The system construction and the inheritance transfer from the basic exploration stage to the scientific and deep development stage. Therefore, the professional development of discipline is of vital importance. Our country should provide folklore and folk literature related to the intangible cultural heritage education, support and integrate relevant majors and carry out professional pilot education according to local characteristics. Furthermore, it is necessary to bring the intangible cultural heritage education in the undergraduate education system, integrate basic humanities 
with applied courses and establish systematic and normative, scientific and reasonable educational mechanism.

\section{Colleges Shall Provide All-Round Support for the Intangible Cultural Heritage Education.}

In order to train excellent people who love, identify and protect the intangible cultural heritage, colleges should free the mind and keep pace with the times, aim at prospering the national culture and care for people. Meanwhile, follow the law of educational development and continuously reform to roundly implement and support the intangible cultural heritage.

Firstly, use scientific educational idea to arouse students' interests in learning intangible cultural heritage. College must change educational idea, management system and mode and create free and diversified cultural environment to support and guarantee the development of intangible cultural heritage in college education. At the same time, it is necessary to increase input in the intangible cultural heritage education for college students, adjust and revise talent training program, establish institutions and break the barriers influencing the management and evaluation of it and provide system guarantee. For example, the protection and research center of intangible cultural heritage formed by multiple disciplines should be established to guide teachers and students to learn, protect and inherit intangible cultural heritage. The center can serve as the platform to build website of intangible cultural heritage. We can use the network to seek extensive, efficient and novel ways of learning.

Secondly, create the campus culture of respecting, inheriting and protecting the intangible cultural heritage. Diversified and active campus culture is of great advantage to arouse students' passion and potential to learn and carry out productive protection of the intangible cultural heritage. Vigorously support college student associations and help them to explore new patterns of intangible cultural heritage activities, combine the knowledge popularization on campus with the practical education outside school. They should make campus culture become national, original, creative and high grade and fresh. It can strengthen college students' traditional cultural accomplishment and national aesthetic taste. The high-grade and connotative campus culture can guide students to have consciousness of responsibility in protecting and inheriting the intangible cultural heritage. For example, they can establish associations to protect the intangible cultural heritage and carry out social activities like field investigation and experience in the original place of intangible cultural heritage, inherit and research it according to normative systems.

Thirdly, improve the professional level of teachers. Colleges should train teachers with professional knowledge and practical skills. These teachers are brave to explore and adept in guiding students to learn intangible cultural heritage. As a new-rising subject, it lacks professionals. Colleges should build a teaching team consisting of college teachers and inheritors of intangible cultural heritage. On one hand, intensify the training of existing teachers, expand their knowledge dimension and improve their teaching ability, reform teaching methods. Teachers become guider and cooperator instead of controller. Lively, democratic and equal learning atmosphere should be created. On the other hand, invite high-level experts and scholars to teach and exchange achievements in scientific research, and inheritors to show on site. They can form teaching team with reasonable structure and comprehensive quality in static support of academic research and lively inheritance of practice.

Lastly, improve the course system. At present, many colleges introduce intangible cultural heritage education in courses, but the course system requires improvement. The course objectives should be clear so that students can grasp methods and skills to protect, inherit and develop as well as love, identify intangible cultural heritage in learning knowledge. Unified planning should be provided for course contents, forms and teaching arrangement. Colleges should understand laws and policies and grasp methods and skills in the protection of intangible cultural heritage, introducing resources in local culture to make the intangible cultural heritage education local, lively and characteristic. Courses like ideology and politics, culture, history and art can be introduced College students can learn skills as apprentice of masters and go to the countryside to investigate. They can receive the education from college teachers and inheritors of intangible cultural heritage. The course assessment can integrate knowledge, practice and scientific research to guide students to pay attention to knowledge accumulation and practical application as well as the theory.

\section{CONCLUSION}

As the backbone in the socialism construction, college students must have a sense of national identity, improve cultural consciousness and deepen the understanding of the importance in intangible cultural heritage. They should strengthen the urgency and the sense of responsibility and provide intelligence guarantee in protection and inheritance of intangible cultural heritage, promoting the deep, continuous and effective implementation of this engineering that benefits the nation and the people.

\section{REFERENCES}

[1] Mu Yanlin, Tan Hong. Inheritance of Intangible Cultural Heritage Education: New Path of Cultural Quality Education in Contemporary Colleges [J], Ethnic Art Studies, Dec.2010

[2] Xu Jinlong. Current Situation of Intangible Cultural Heritage for College Students and Countermeasures [J], Journal of Gannan Normal University, Jan.2009

[3] Zhang Taicheng, He Jianliang. Research on Path of Integrating Intangible Cultural Heritage in College Education [J], Journal of National Academic of Education Administration, Dec.2012

[4] Song Guobin, Hu Shaozong. Introduction to Intangible Cultural Heritage in the Eastern Hubei Province [M], Beijing Arts and Crafts Publishing House, Jun.2012 